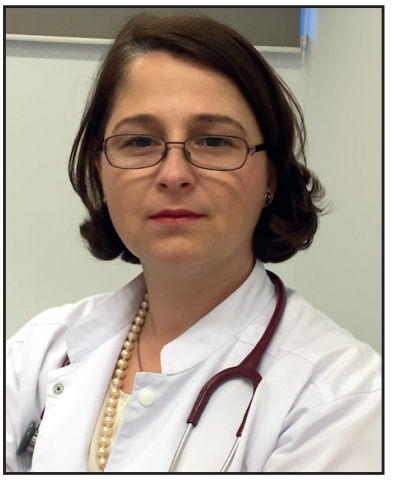

Camelia DIACONU ${ }^{凶}$

International Secretary General of the Balkan Medical Union

President of the Romanian National Section

Secrétaire Général International de l'Union Médicale Balkanique

Présidente de la Section Nationale Roumaine

\section{DOES THE TREATMENT WITH PCSK9 INHIBITORS INCREASE THE RISK OF TYPE 2 DIABETES?}

Cardiovascular diseases are major comorbidities in patients with type 2 diabetes mellitus. Diabetic patients often receive treatment with lipid-lowering drugs. Statins are first-line therapy for high levels of low-density lipoprotein-cholesterol (LDL-C), aiming to decrease the risk of atherosclerotic cardiovascular disease, as a main cause of death in diabetic patients ${ }^{1}$. Their widespread use led to a significant decrease in cardiovascular morbidity and mortality. There is increasing evidence that lipid-lowering medication (especially statins) increases the risk of type 2 diabetes in nondiabetic patients. However, their modest diabetogenic effect does not outweigh their benefits in patients with established cardiovascular disease or those at high risk.

Proprotein convertase subtilisin/kexin type 9 (PCSK9) inhibitors have emerged as a new class of drugs, with hypocholesterolemiant properties, recently approved by the Food and Drug Administration ${ }^{1}$. They are monoclonal antibodies that inactivate the proprotein convertase subtilisin/kexin type 9 , enabling low-density lipoprotein receptor degradation. The PCSK9 inhibitors alirocumab and evolocumab may be used in patients with diabetes, when statin therapy alone, in high doses, does not succeed to lower the LDL-C levels². Despite their benefits in lowering the cardiovascular risk, treatment with

\section{LE TRAITEMENT AVEC LES INHIBITEURS PCSK9 AUG- MENTE-T-IL LE RISQUE DE DIABÈTE DE TYPE 2?}

Les maladies cardiovasculaires sont des comorbidités majeures chez les patients atteints de diabète de type 2. Les patients diabétiques reçoivent souvent un traitement par des médicaments hypolipidémiants. Les statines constituent un traitement de première intention pour les taux élevés de cholestérol à lipoprotéines de basse densité (LDL-C), dans le but de réduire le risque de maladie cardiovasculaire athéroscléreuse, principale cause de décès chez les patients diabétiques ${ }^{1}$. Leur utilisation généralisée a entraîné une diminution significative de la morbidité et de la mortalité cardiovasculaires. Il est de plus en plus évident que les médicaments hypolipidémiants (en particulier les statines) augmentent le risque de diabète de type 2 chez les patients non diabétiques. Cependant, leur effet diabétogène modeste n'est plus grand que leurs avantages chez les patients présentant une maladie cardiovasculaire établie ou à risque élevé.

Les inhibiteurs de la proprotéine convertase subtilisine / kexine de type 9 (PCSK9) sont apparus comme une nouvelle classe de médicaments, aux propriétés hypocholestérolémiantes, récemment approuvés par la Food and Drug Administration ${ }^{1}$. Ce sont des anticorps monoclonaux qui inactivent la subtilisine / kexine de type 9 de la proprotéine convertase, permettant ainsi la dégradation des récepteurs de lipoprotéines de faible densité. Les inhibiteurs de la PCSK9, alirocumab et evolocumab, 
PCSK9 inhibitors may lead to an increase in the risk of incident diabetes. However, current data suggest that the benefits of treatment with PCSK9 inhibitors outweigh this risk. A systematic review and metaanalysis with over 96,000 patient-years, done by de Carvalho et al, evaluated the effects of PCSK9 inhibitors versus placebo in patients with primary hypercholesterolemia ${ }^{3}$. This meta-analysis concluded that treatment with PCSK9 inhibitors increased fasting serum glucose levels and HbA1c, compared to placebo, but this effect did not lead to an increased incidence of diabetes ${ }^{3}$. An association has been found between the potency and duration of treatment with PCSK9 inhibitors and the increased risk of diabetes ${ }^{3}$.

In an analysis of FOURIER trial, Sabatine et al investigated the efficacy and safety of a PCSK9 inhibitor, evolocumab, depending on diabetes status, and its risk of developing diabetes ${ }^{4}$. FOURIER trial included 27,564 patients with atherosclerotic cardiovascular disease, treated with statins, who were followed for 2.2 years. At the beginning of the study, $40 \%$ of patients had diabetes and $60 \%$ did not have diabetes. Treatment with evolocumab did not increase the risk of new-onset diabetes ${ }^{4}$. Also, the levels of HbAlc and fasting serum glucose were similar between the groups treated with evolocumab and placebo, in patients with diabetes or those non-diabetic ${ }^{4}$. The authors concluded that treatment with evolocumab is not associated with a higher risk of new-onset diabetes $^{4}$. However, the follow-up period of these patients was only 2.2 years. Their data remain to be confirmed by studies with a longer follow-up period.

Da Dalt et al investigated the molecular mechanisms behind the association between the PCSK9 loss of function genetic variants and the higher serum glucose levels and increased risk of new-onset type 2 diabetes in mice ${ }^{5}$. They have found that PCSK9 deficiency is associated with impaired glucose tolerance, but not with insulin resistance ${ }^{5}$. PCSK9 effect on glucose metabolism depends on the presence of the low-density lipoprotein receptor ${ }^{5}$. Genetic deletion of PCSK9 in mice is associated with glucose intolerance 5 .

Large, long-term studies with PCSK9 inhibitors will surely offer responses to questions regarding the correlation of these drugs with the risk of new-onset diabetes. peuvent être utilisés chez les patients diabétiques lorsque le traitement à la statine seul, à fortes doses, ne permet pas d'abaisser les taux de LDL-C². Malgré leurs avantages à réduire le risque cardiovasculaire, le traitement par les inhibiteurs de la PCSK9 peut entraîner une augmentation du risque de diabète incident. Cependant, les données actuelles suggèrent que les avantages du traitement avec les inhibiteurs de la PCSK9 sont plus grandes que ce risque. Une revue systématique et une méta-analyse portant sur plus de 96,000 patients-années, réalisées par de Carvalho et al, ont évalué les effets des inhibiteurs de la PCSK9 par rapport au placebo chez les patients atteints d'hypercholestérolémie primaire ${ }^{3}$. Cette méta-analyse a conclu que le traitement par les inhibiteurs de la PCSK9 augmentait les taux de glucose sérique à jeun et le taux d'HbA1c par rapport au placebo, mais que cet effet n'entraînait pas une augmentation de l'incidence du diabète ${ }^{3}$. Une association a été établie entre la puissance et la durée du traitement avec les inhibiteurs de la PCSK9 et le risque accru de diabète ${ }^{3}$.

Dans une analyse de l'étude FOURIER, Sabatine et al ont étudié l'efficacité et l'innocuité d'evolocumab, un inhibiteur de la PCSK9, en fonction du statut diabétique et de son risque de développer le diabète ${ }^{4}$. L'étude FOURIER a inclus 27,564 patients atteints de maladie cardiovasculaire athéroscléreuse, traités avec des statines, suivis pendant 2,2 ans. Au début de l'étude, $40 \%$ des patients étaient diabétiques et 60\% non diabétiques. Le traitement par evolocumab n'a pas augmenté le risque de diabète d'apparition récente $^{4}$. En outre, les taux d'HbA1c et de glucose sérique à jeun étaient similaires dans les groupes traités par evolocumab et par placebo, chez les patients diabétiques ou non diabétiques ${ }^{4}$. Les auteurs ont conclu que le traitement par evolocumab n'était pas associé à un risque plus élevé de diabète nouvellement apparu ${ }^{4}$. Cependant, la période de suivi de ces patients n'était que de 2,2 ans. Leurs données restent à confirmer par des études avec une période de suivi plus longue.

Da Dalt et al ont étudié les mécanismes moléculaires à l'origine de l'association entre les variants génétiques avec perte de fonction PCSK9 et des taux de glucose sérique plus élevés et un risque accru de diabète de type 2 nouvellement apparu chez la souris $^{5}$. Ils ont découvert que le déficit en PCSK9 était associé à une tolérance au glucose altérée, mais pas à une résistance à l'insuline ${ }^{5}$. L'effet de PCSK9 sur le métabolisme du glucose dépend de la présence du récepteur de lipoprotéines de faible densité ${ }^{5}$. La suppression génétique de PCSK9 chez la souris est associée à une intolérance au glucose ${ }^{5}$.

De vastes études à long terme sur les inhibiteurs de la PCSK9 apporteront certainement des réponses aux questions concernant la corrélation de ces médicaments avec le risque de diabète d'apparition récente. 


\section{„No conflict of interest.“}

\section{References}

1. Handelsman Y, Lepor NE. PCSK9 inhibitors in lipid management of patients with diabetes mellitus and high cardiovascular risk: a review. J Am Heart Assoc. 2018;7(13):1-25.

2. Chamberlain JJ, Johnson EL, Leal S, Rhinehart AS, Shubrook JH, Peterson L. Cardiovascular disease and risk management: review of the American Diabetes Association standards of medical care in diabetes 2018. Ann Intern Med. 2018;168(9):640-650.

3. de Carvalho LSF, Campos AM, Sposito AC. Proprotein convertase subtilisin/kexin type 9 (PCSK9) inhibitors and incident type 2 diabetes: a systematic review and meta-analysis with over 96,000 patient-years. Diabetes Care. 2018;41(2):364-367.

4. Sabatine MS, Leiter LA, Wiviott SD, et al. Cardiovascular safety and efficacy of the PCSK9 inhibitor evolocumab in diabetes and the risk of development of diabetes: a prespecified analysis from the randomized controlled FOURIER trial. Lancet Diabetes Endocrinol. 2017;5(12):941-950.

5. Da Dalt L, Ruscica M, Bonacina F, et al. PCSK9 deficiency reduces insulin secretion and promotes glucose intolerance. The role of the low-density lipoprotien receptor. Eur Heart J. 2019;40(4):357-368. 